\title{
Wacana Solidaritas Muslim Indonesia dalam Teks Pengungsi Muslim Etnis Rohingya Pada Media Daring Viva.co.id
}

\author{
Eggy Fajar Andalas \\ Pendidikan Bahasa dan Sastra Indonesia, Universitas Muhammadiyah Malang \\ eggy@umm.ac.id
}

\begin{abstract}
Abstrak
Penelitian ini bertujuan untuk membedah strategi pembentukan wacana solidaritas muslim Indonesia dalam kasus mulim Rohingya oleh media massa Indonesia. Untuk melakukan hal tersebut dimanfaatkan teori analisis wacana Theo Van Leeuwen. Metode yang digunakan adalah analisis isi. Sumber data penelitian adalah tujuh teks berita daring dari media massa viva.co.id. Hasil penelitian menunjukkan konstruksi wacana yang dibangun cenderung mengedepankan citra Indonesia sebagai bangsa dengan umat muslim terbesar di dunia sebagai pahlawan kemanusiaan. Motif penggambaran wacana kemanusiaan dibangun melalui isu agama dan kemanusiaan. Konstruksi tersebut berdampak terhadap pemarjinalan kelompok lain. Pemerintah Myanmar justru lebih digambarkan dengan beragam citra negatif, begitu juga dengan para pengungsi Rohingya yang selalu digambarkan sebagai kelompok yang benarbenar sedang kesusahan dan benar-benar membutuhkan bantuan. Terdapat bobot pemberitaan yang tidak seimbang yang dilakukan oleh media viva.co.id yang berdampak pada pemarjinalan kelompok ini.
\end{abstract}

\section{Abstract}

This study aims to uncover the strategy of forming Indonesian Muslim discourse in the Rohingya case by Indonesian mass media. This study used discourse analysis theory by Theo van Leeuwen. The method used is content analysis. The data sources of this study are seven online news text from viva.co.id. The result show that the construction of discourse that is built tends to prioritize the image of Indonesia as a nation with the largest Muslim ummah in the world as a hero of humanity. The motive for depicting humanitarian discourse was built through religious and humanitarian issues. The construction affects the marginalization of other groups. The Myanmar government is actually more depicted with a variety of negative images, as well as Rohingya refugees who are always described as a group that is really in trouble and really need help. There is an unbalanced reporting weight carried out by viva.co.id media which has an impact on the marginalization of this group. 


\section{PENDAHULUAN}

Permasalahan yang akhir-akhir ini mencuat mengenai aksi penyelamatan nelayan Aceh terhadap para pengungsi Rohingya yang akan pergi mencari suaka ke Malaysia telah menghiasi pemberitaan nasional setiap harinya. Perhatian media nasional terhadap permasalahan ini semakin besar mengingat permasalahan mengenai banyak warga etnis Rohingya yang mencari suaka ke negaranegara lain untuk menyelamatkan dirinya dari penindasan yang dilakukan terhadapnya di Myanmar telah menjadi permasalahan internasional. Tidak sedikit negara yang mengecam mengenai tindakan yang dilakukan pemerintah Myanmar terhadap warganya. Bahkan pemerintah Myanmar tidak mengakuinya sebagai warga negara Myanmar. Seperti dilansir dari laman www.viva.co.id berikut.

Pemerintah Myanmar sering menjuluki etnis Rohingya sebagai 'Kaum Bengali'. Sebab, Myanmar tidak mau mengakui kaum tersebut sebagai warga negaranya. Menurut Pemerintah Myanmar, 'Kaum Bengali' merupakan pendatang gelap dari negara tetangga mereka, Bangladesh.

Sikap pemerintah Myanmar terhadap etnis Rohingya sebenarnya telah terjadi sejak lama. Akan tetapi, kerusuhan yang terjadi pada bulan Juni lalu memicu perhatian dunia internasional. Dilansir dari laman okezone.com (8 November 2015), Presiden Thein Sein pun tidak ingin mengakui kewarganegaraan dari etnis tersebut, bahkan lebih memilih untuk mendeportasi serta mengumpulkannya dalam tempat penampungan.

Bila ditilik lebih mendalam, pembantaian hingga pengusiran yang dilakukan oleh pemerintah Myanmar telah membuka mata dunia untuk lebih memperhatikan nasib ratusan bahkan ribuan warga etnis Rohingya yang berada di Myanmar. Akan tetapi, mengenai hal tersebut Staf Analisis Bidang Pertahanan Deputi Budang Polhukan, Agil (www.setkab. go.id) mengatakan bahwa kepedulian terhadap Etnis Rohingya oleh dunia internasional dirasa masihlah kurang, sehingga mengakibatkan semakin membabibutanya pemerintahan Myanmar membunuh dan mengusir muslim Rohingya.

Sikap dari pemerintah Myanmar terhadap etnis Rohingya tersebutlah kini yang menjadi topik hangat dalam pemberitaan media internasional, khususnya nasional. Setelah peristiwa penyelamatan nelayan Aceh terhadap para pengungsi Rohingya yang terkatungkatung di laut berusaha mencari suaka ke Malaysia diberitakan oleh media., tidak sedikit warga Indonesia yang bersimpati memberikan bantuannya terhadap para pengungsi. Pemerintah Indonesia bahkan menyediakan tempat pengungsian sebagai tempat penampungan sementara warga Rohingya. Peran warga pun juga tidak kalah, banyak dari mereka yang memberikan bantuannya, seperti memberikan pelajaran berbahasa Indonesia, memberikan bantuan berupa jasa sesuai keahlian mereka, menghibur anak-anak pengungsian, membantu menyediakan masakan di dapur pengungsian, dan lain-lain. Hingga kini ratusan pengungsi Rohingya yang berhasil diselamatkan oleh nelayan masih menghuni pengungsian yang berada di Aceh.

Berdasarkan hal tersebut, jelaslah terlihat peran media dalam membentuk opini masyarakat. Media tidak hanya bertindak sebagai medium pemberitaan saja, tetapi mampu membentuk bahkan berdampak terhadap para pembacanya. Kehadiran situssitus berita daring, seperti vivanews.com, kompas.com, tribunnews.com, detik.com, 
okezone.com, dan beragam media berita daring lainnya secara tidak langsung telah merubah sikap dan cara pemerolehan informasi masyarakat.

Media daring merupakan produk dari jurnalistik online atau cyber journalism yang didefinisikan sebagai pelaporan fakta atau persitiwa yang diproduksi dan didistribusikan melalui internet (Romli, 2012: 30). Dengan hadirnya media daring dalam dunia jurnalistik berdampak pada masyarakat. Kini masyarakat tidak lagi hanya bergantung pada media konvensional untuk mengikuti perkembangan peristiwa yang terjadi. Dampak yang ditimbulkannya yaitu kecenderungan masyarakat untuk mengikuti pemberitaan melalui beberapa situs berita daring. Didasarkan pada studi Ognaniova (dalam Romli, 2012:37) ditemukan bahwa situs berita yang terkait dengan jaringan surat kabar atau televisi dianggap lebih kredibel daripada situs yang tidak terkait dengan oraganisasi atau perusahaan media. Akan tetapi, netralitas megenai suatu pemberitaan tidaklah menjadi suatu jaminan mengenai pemberitaan suatu peristiwa yang dilakukan oleh suatu media. Seperti media viva.co.id yang dimiliki oleh Bakrie Grup. Isuisu mengenai permasalahan etnis Rohingya menjadi salah satu pemberitaan penting yang disajikan dalam laman berita online ini. Oleh karena itu, didasarkan pada permasalahan tersebut dilakukan kajian terhadap upaya konstruksi pemberitaan yang dilakukan oleh media daring viva.co.id mengenai solidaritas muslim Indonesia terhadap etnis muslim Rohingya.

Studi mengenai pembentukan citra suatu aktor dalam suatu pemberitaan media massa pernah dilakukan pada beberapa penelitian sebelumnya, yaitu 1) Suganda dkk. (2007) dengan judul Representasi Sosok Tenaga Kerja Wanita (TKW) Indonesia dalam Wacana Berita Pada Harian Umum Utusan Malaysia dan Harian Umum Kompas Indonesia: Kajian Analisis Wacana Kritis, 2) Fitriyani (2011) dengan judul Analisis Wacana Kritis Pencitraan Susilo Bambang Yudhoyono Sebagai Politikus dalam Buku Pak Beye dan Politiknya Terbitan PT. Kompas Media Nusantara, dan 3) Penelitian Ardianto (2012) dengan judul Analisis Wacana Kritis Pemberitaan Harian Pikiran Rakyat dan Harian Kompas Sebagai Public Relations Politik dalam Membentuk Branding Reputation Presiden Susilo Bambang Yudhoyono (SBY).

Pertama, penelitian Suganda dkk (2007) dengan judul Representasi Sosok Tenaga Kerja Wanita (TKW) Indonesia dalam Wacana Berita Pada Harian Umum Utusan Malaysia dan Harian Umum Kompas Indonesia: Kajian Analisis Wacana Kritis bertujuan mendeskripsikan sosok Tenaga Kerja Wanita (TKW) direpresentasikan melalui bahasa dalam dua harian umum nasional yang ada di Indonesia dan Malaysia. Hasil penelitian menunjukan bahwa kedua media massa nasional tersebut sama-sama merepresentasikan TKW Indonesia sebagai sosok yang marjinal, tidak mempunyai kekuatan dan kekuasaan, kampungan, tidak berpendidikan, miskin, bodoh, dan lain-lain. Dalam pemberitaan, TKW lebih banyak menjadi pihak yang dihadirkan melalui strategi bahasa yang merepresentasikan mereka secara buruk, sedangkan pihak penguasa (majikan, media massa, pemerintah, dan lain-lain) lebih banyak menjadi pihak yang dikeluarkan dalam pemberitaan dengan tujuan untuk melindungi pihak penguasa. 
Kedua, penelitian Fitriyani (2011) dengan judul Analisis Wacana Kritis Pencitraan Susilo Bambang Yudhoyono Sebagai Politikus dalam Buku Pak Beye dan Politiknya Terbitan PT. Kompas Media Nusantara bertujuan meneliti politik pencitraan Presiden Susilo Bambang Yudhoyono. Penelitian ini menggunakan metode analisis wacana kritis Van Dijk. Hasil penelitian yang dilakukan menunjukkan bahwa pencitraan yang terbangun merupakan pencitraan negatif dengan kritik yang disampaikan terasa tajam dalam mengkritisi SBY selaku politikus. Posisi penulis (Wisnu) netral dalam menyampaikan pemberitaan. Selain itu, kelebihan dan kekurangan SBY diungkapkan dalam buku Pak Beye dan Politiknya. Di berbagai artikel yang disampaikan pun tergambarkan pencitraan SBY sebagai sosok seorang politikus yang sensitif terhadap kritikan, ulung dalam politik pencitraan, dan eksploitatif.

Ketiga, penelitianArdianto (2012) dengan judul Analisis Wacana Kritis Pemberitaan Harian Pikiran Rakyat dan Harian Kompas Sebagai Public Relations Politik dalam Membentuk Branding Reputation Presiden Susilo Bambang Yudhoyono (SBY) bertujuan mendeskripsikan konstruksi wacana pemberitaan Susilo Bambang Yudhoyono pada Koran Harian Pikiran Rakyat dan Harian Kompas. Metode penelitian yang digunakan mengacu pada perspektif Norman Fairclough. Hasil penelitian menunjukkan bahwa produksi teks Pikiran Rakyat cenderung branding reputation negatif terhadap Presiden SBY, sedangkan produksi teks Kompas cenderung branding reputation positif terhadap Presiden SBY. Konsumsi teks Pikiran Rakyat adalah pembaca mempersepsi sama (negatif) dengan produksi teks yang dibuat oleh Pikiran Rakyat, sedangkan konsumsi teks Kompas adalah pembaca berseberangan (negatif) dengan produksi teks yang dibuat oleh Kompas, yaitu pemberitaan cenderung branding reputation positifPresiden SBY.

Berdasakan hal tersebut terdapat persamaan penelitian ini dengan penelitianpenelitian sebelumnya, yaitu bertujuan membongkar konstruksi wacana aktor sosial yang direpresentasikan dalam suatu pemberitaan media massa. Akan tetapi, terdapat perbedaan penelitian ini dengan penelitianpenelitian sebelumnya, yaitu penelitian ini melihat secara lebih mendalam mengenai strategi yang digunakan oleh media massa dan dampak dari konstruksi wacana tersebut terhadap kelompok lain. Untuk melakukan hal tersebut digunakan teoriAnalisis Wacana Theo Van Leeuwen. Hal tersebut didasarkan pada pertimbangan 1) tujuan dari penelitian yaitu melihat bagaimana wacana muslim Indonesia dalam membantu pengungsi etnis Rohingya sebagai sesama umat muslim dibentuk melalui pemberitaan media massa elektronik viva.co.id akan melibatkan dua aktor, yaitu aktor yang dimunculkan sebagai sebagai kelompok yang dominan dan akan adanya penghilangan aktor lain untuk mengedepankan aktor yang dimunculkan 2) melalui proses ekslusi dan inklusi yang dijabarkan oleh Van Leeuwen akan ditemukan mengenai bagaimana strategi wacana yang digunakan oleh media massa viva.co.id dalam memberitakan suatu peristiwa, apakah terdapat aktor yang dikeluarkan dan bagaimana media tersebut memunculkan aktor/pelaku dalam pemberitaan. Dengan dilakukannya kajian dengan menggunakan model Van Leeuwen seperti yang dijabarkan pada beberapa hal di atas akan dapat ditarik kesimpulan mengenai bagaimana media massa 
viva.co.id dalam memberitakan mengenai muslim Indonesia sebagai bagian dari muslim dunia dalam membantu pengungsi muslim etnis Rohingya yang sedang dalam kondisi kesulitan. Secara rinci rumusan masalah dalam penelitian ini, yaitu 1) bagaimana representasi Etnis Muslim Rohingya dalam teks berita civa.co.id? 2) bagaimana solidaritas Bangsa Indonesia dalam membantu pengungsi Etnis Muslim Rohingya dibentuk dalam teks berita viva.co.id, dan 3) bagaimana dampak pembentukan wacana solidaritas Muslim Indonesia terhadap Muslim Rohingya bagi kelompok lain?

\section{KAJIAN PUSTAKA}

Pada dasarnya Theo Van Leeuwen memperkenalkan model analisis wacana untuk mendeteksi dan meneliti bagaimana suatu kelompok atau seseorang dimarjinalkan posisinya dalam suatu wacana (Eriyanto, 2012:171). Hubungan tersebut berkaitan dengan dominasi kelompok yang dominan terhadap pembentukan makna dan menafsirkan suatu peristiwa dibandingkan dengan kelompok lainnya. Untuk membedah permasalahan tersebut, terdapat dua konsepsi yang diketengahkan oleh Van Leeuwen, yaitu eksklusi dan inklusi. Eksklusi berkaitan dengan pengeluaran suatu aktor dari pembicaraan, sedangkan inklusi berkaitan dengan cara media dalam menampilkan masing-masing aktor dalam suatu pemberitaan. Ada tiga cara yang dapat dilakukan melalui proses ekslusi, yaitu pasivasi, nominalisasi, dan penggantian anak kalimat. Pertama, pasivasi berkaitan dengan pengeluaran suatu aktor sosial dari suatu pemberitaan dengan cara mengubah kata aktif menjadi pasif. Kedua, nominalisasi berkaitan dengan mengubah kata kerja menjadi kata benda. Ketiga, penggantian anak kalimat digunakan sebagai pengganti aktor. Van Leeuwen bahkan menyatakan bahwa ekslusi merupakan salah satu aspek terpenting dalam analisis wacana kritis (Leeuwen, 2008:28), hal tersebut karena suatu aktor dapat dikeluarkan dalam suatu pemberitaan tanpa harus mengubah esensi peristiwa yang dihasilkan dalam suatu pemberitaan. Begitupun dalam inklusi. Cara media dalam menampilkan aktor dapat dilakukan dengan beberapa cara. Dikutip dari Eriyanto (2012:179-192), proses inklusi dapat dilakukan dengan 1) diferensiasiindiferensiasi, 2) objektivasi-abstraksi, 3) nominasi-kategorisasi, 4) nominasi-identifikasi, 5) determinasi-indeterminasi, 6) asimilasiindividualiasi, dan 7) asosiasi-disosiasi.

Pertama, diferensiasi-indiferensiasi berkaitan dengan hadirnya peristiwa atau kelompok lain sebagai perbandingan tindakan dalam suatu pemberitaan. Kedua, objektivikasiabstraksi berkaitan dengan upaya penggambaran kejadian yang dilakukan dalam pemberitaan, apakah didasarkan pada peristiwa konkret atau hanya berupa abstraksi. Ketiga, nominasikategorisasi berkaitan dengan pemilihan pengemukaan identifikasi individu, apakah didasarkan apa adanya atau dalam kategorikategori (jenis kelamin, ras, agama, fisik, dll). Keempat, nominasi-identifikasi berkaitan dengan hadirnya anak kalimat atau proposisi tambahan sebagai bentuk penjelasan terhadap proposisi pertama. Kelima, determinasiindeterminasi berkaitan dengan penyebutan atau identifikasi aktor yang ditampilkan apakah merujuk pada penyebutan secara jelas (nama) ataupun identifikasi berdasarkan anonimitas. Keenam, asimilasi-individualisasi berkaitan dengan pemaparan mengenai kategori aktor sosial, apakah aktor sosial spesifik yang disebut ataukah komunitas atau kelompok sosialnya 
yang disebut. Ketujuh, asosiasi-disosiasi berkaitan dengan pemberitaan aktor sosial yang diarahkan pada individunya atau dihubungkan dengan kelompok lain yang lebih besar.

\section{METODE PENELITIAN}

Penelitian ini merupakan jenis penelitian kualitatif dengan metode analisis isi. Metode analisis isi yaitu metode yang biasa digunakan untuk memahami pesan simbolik dari suatu wacana atau teks (Badara, 2012:63), dalam hal ini ialah teks berita mengenai pengungsi etnis Rohingya yang diunduh dari laman okezone.com. Pendekatan yang digunakan dalam penelitian ini yaitu pendekatan kritis. Menurut Guba dan Lincoln pendekatan kritis yaitu pendekatan yang memusatkan perhatian terhadap pembongkaran aspek-aspek tersembunyi di balik sebuah kenyataan yang tampak, guna dilakukannya kritik dan perubahan terhadap struktur sosial (Denzin dan Lincoln, 1994:105-106). Sumber data penelitian ini yaitu ketujuh teks berita dengan judul Ratusan Pengungsi Rohingya Telah Dipindahkan ke Tempat Baru (14/05/2015), Hizbut Tahrir Kritik Sikap Diam Suu Kyi soal Rohingya (29/05/2015), Cari Solusi Rohingya, Asisten Menlu AS Sambangi RI(29/05/2015), Gerakan 'Save Rohingya' untuk Perayaan Waisak di Kota Batu (2/06/2015), Pemda Aceh Bangun Komplek Pengungsi Rohingya (4/06/2015), Wali Kota Banda Aceh: Kuasai Alquran, Rohingya Kuasai Dunia (19/06/ 2015), Cabai, Sirih dan Kisah Tarawih Etnis Rohingya (20/06/2015). Data yang digunakan dalam penelitian ini yaitu kalimat ataupun kumpulan kalimat yang memperlihatkan mengenai representasi Etnis Rohingya dalam teks berita viva.co.id, upaya Indonesia dalam membantu pengungsi Etnis Muslim Rohingya, dan pemarjinalan suatu kelompok dalam teks berita. Teknik analisis data dalampenelitian ini yaitu 1) mendeskripsikan mengenai bagaimana Etnis muslim Rohingya digambarkan dalam teks media viva.co.id. Analisis meliputi kalimat ataupun kumpulan kalimat yang memperlihatkan bagaimana Etnis Rohingya digambarkan dalam teks berita. 2) Analisis terhadap bagaimana upaya pemerintah dan warga Indonesia dalam membantu pengungsi Etnis Muslim Rohingya, dan 3) menguraikan dampak dari pembentukan wacana solidaritas muslim Indonesia terhadap pengungsi muslim Rohingya, hingga melihat potensi adanya kelompok yang termarjinalkan di dalam teksteks tersebut.

\section{PEMBAHASAN}

Untuk menjawab permasalahan mengenai bagaimana media viva.co.id dalam membentuk wacana solidaritas muslim Indonesia dalam membantu muslim Rohingya akan dipaparkan dalam beberapa sub-bab seperti yang telah dijelaskan pada bab teknik analisis data pada bab sebelumnya. Pembahasan meliputi 1) representasi etnis muslim Rohingya dalam teks berita viva.co.id, 2) soldiaritas Indonesia dalam membantu pengungsi Etnis Muslim Rohingya dalam teks berita viva.co.id, dan 3) dampak pembentukan wacana solidaritas muslim Indonesia terhadap muslim Rohingya bagi kelompok lain.

\section{Representasi Etnis Muslim Rohingya dalam Teks Berita Viva.co.id}

Representasi merujuk pada bagaimana kelompok, individu, ataupun gagasan tertentu yang ditampilkan dalam sebuah wacana. Dalam konteks ini, representasi yang dimaksud, yaitu mengenai bagaimana wacana teks berita 
pada media berita online viva.co.id dalam menggambarkan Etnis Muslim Rohingya dalam teks-teks beritanya. Bahkan Ibrahim dan Suranto (1998, 337), menyatakan bahwa media tampil sebagai aparatus teknis kapitalisme dan komoditas simbol-simbol budaya massa atau populer yang melingkupinya. Oleh karenanya, melalui pemberitaan mengenai bagaimana media massa dalam merepresentasikan Etnis Muslim Rohingya akan berdampak terhadap pembentukan opini dan cara pandang masyarakat terhadap objek pemberitaannya. Melalui pemberitaan media viva.co.id, Etnis Muslim Rohingya dijadikan sebagai sebuah komoditi untuk menggerakkan pemikiran masyarakat mengenai bagaimana menerima atau berfikir mengenai kondisi Etnis Rohingya yang berada di pengungsian Aceh.

Berdasarkan pada ketujuh teks yang berasal dari laman viva.co.id dengan tema pemberitaan mengenai pengungsi Etnis Muslim Rohingya di Aceh, keseluruhan teks menggambarkan para pengungsi tersebut sebagai kumpulan manusia yang tertindas dan tidak memperoleh haknya secara adil, sehingga patut untuk mendapat perhatian serta pertolongan dari warga dan pemerintah Indonesia, bahkan dunia. Seperti pemberitaan dengan judul Cari Solusi Rohingya, Asisten Menlu AS Sambangi RI (29/05/2015). Dalam pemberitaan tersebut terlihat permasalahan mengenai etnis Rohingya tidak lagi hanya menjadi permasalahan dalam negeri Myanmar ataupun regional kawasan Asia Tenggara, akan tetapi telah menjadi permasalahan dunia sehingga Amerika Serikat sebagai salah satu negara yang perduli terhadap persoalan kemanusiaan dunia ikut campur dalam permasalahan ini. Delegasi AS, Anne C Richard menghadiri pertemuan di tiga negara untuk memperbincangkan permasalahan ini, yaitu di Thailand, Indonesia, dan Malaysia. Ketiga negara merupakan tujuan pengungsi Etnis Rohingya yang lari dari Myanmar akibat penindasan yang diterimanya selama di sana. Untuk mendukung pernyataan sebelumnya, dalam pemberitaan juga disertakan beberapa opini yang menambah validitas dari pernyataan sebelumnya, seperti dalam kutipan berita berikut. AS pun akan bekerja sama dengan badan
PBB, UNHCR, untuk memukimkan
pengungsi Rohingya ke negara ketiga.
Mereka pun menyadari pemukiman kembali
bukan solusi utama dalam krisis tersebut,
tetapi dapat menjadi salah satu upaya
regional yang lebih luas.
Upaya ini agar mereka bisa mengatasi akar
permasalahan migrasi dan menciptakan
solusi bagi mereka yang kabur karena
takut. AS telah memukimkan sekitar 150
ribu pengungsi sejak 10 tahun terakhir,
termasuk 1.000 warga Rohingya tahun ini.

Teks pemberitaan lain yang membentuk bagaimana pengabaian dan realitas penindasan yang terjadi pada Etnis Rohingya dibentuk dan diperkuat dengan teks berita berjudul Hizbut Tahrir Kritik Sikap Diam Suu Kyu Soal Rohingya (29/05/2015). Dalam pemberitaan tersebut diperlihatkan sikap Hizbut Tahrir sebagai salah satu ormas Islam terbesar di Indonesia mengkritisi sikap diam pemimpin oposisi Myanmar, Aung San Suu Kyi mengenai pengungsi Rohingya, padahal Suu Kyi merupakan peraih nobel perdamaian dunia. Melalui pemberitaan ini terlihat realitas mengenai kondisi yang terjadi di Myanmar terhadap masyarakat Etnis Rohingya. Dalam kondisi politik dalam negeripun meskipun terdapat seorang tokoh dunia yang memperoleh nobel perdamaian dunia, Etnis Rohingya sama sekali tidak mendapat pembelaan dan sikap apapun. Kondisi inipun semakin meneguhkan mengenai bagaimana konstruksi representasi 
mengenai Etnis Rohingya sebagai masyarakat tertindas tanpa dukungan dari siapapun di dalam negerinya dibentuk.

\section{Solidaritas Indonesia dalam Membantu Pengungsi Etnis Muslim Rohingya dalam Teks Berita Viva.co.id}

Keberadaan ratusan pengungsi Rohingya yang diselamatkan oleh nelayan Aceh beberapa bulan yang lalu telah menghadirkan perhatian tersendiri dari Bangsa Indonesia. Hal tersebut tidak lain berkaitan dengan isu-isu seperti kemanusiaan dan agama. Permasalahan mengenai Etnis Rohingya sejatinya telah lama berlangsung, akan tetapi dengan maraknya pemberitaan media massa nasional, khususnya viva.co.id, dengan beragam isi pemberitaan yang diberitakan telah menggungah perasaan warga dan pemerintah Indonesia untuk membantu mereka. Dampak dari pemberitaan mengenai permasalahan ini dalam media-media nasional telah menimbulkan efek yang luar biasa. Tidak sedikit masyarakat Indonesia dari berbagai agama, ras, dan golongan yang tergugah hatinya untuk membantu. Seperti yang diberitakan dalam laman viva.co.id dengan judul Gerakan 'Save Rohingya' untuk Perayaan Waisak di Kota Batu (2/06/2015). Dalam pemberitaan dikutip sejumlah argumentasi dan pendapat dari para pemuka Buddha di Vihara Padepokan Dhammadipa Arama, Kota Batu, dalam menggalang dana bantuan untuk para pengungsi Rohingya. Dalam berita juga digambarkan mengenai pendapat para umat Buddha dalam melihat persoalan ini, seperti dalam kutipan berita berikut.

Mereka mengeaskan rasa kecewa terhadap pemerintah Myanmar, yang mereka sebut berlawanan dengan nilainilai kemanusiaan. Para pengunjung vihara tak segan mengisi kotak amal, baik saat masuk maupun keluar dari
vihara...Aksi penggalangan Dana dilakukan dengan kerja sama antara umat Buddha Kota Batu dengan komunitas Muslim Majelis Taklim dan Dakwah Husnul Khotimah...Umat Buddha Kota Batu juga meminta pada Kedutaan Besar Myanmar di Jakarta, agar kekejaman terhadap Rohingya dihentikan. Juga imbauan pada seluruh vihara di Malang untuk memasang spanduk 'Save Rohingya'.

Dalam teks di atas terlihat upaya yang dilakukan oleh warga dari berbagai golongan dan agama dalam membantu sesama yang dilandasi rasa kemanusiaan. Pembentukan wacana solidaritas yang didasarkan pada rasa sesama umat muslim juga disoroti dalam laman pemberitaan viva.co.id. Seperti pemilihan teks berita dengan judul Cabai, Sirih, dan Kisah Tarawih Etnis Rohingya (20/05/2015). Melalui teks berita ini, media ingin memperlihatkan peran masyarakat Indonesia, khususnya Aceh dalam membantu para pengungsi sesama muslim dalam menghadapi cobaan. Melalui konstruksi wacana yang menyentuh hati pembacanya, wacana mengenai solidaritas umat muslim Indonesia dalam membantu muslim Rohingya diperlihatkan. Melalui acara buka puasa yang diadakan oleh Wali Kota Banda Aceh Illiza Sa'aduddin, konstruksi berita juga menampilkan sisi lain yang menggungah rasa dari para pembacanya. Seperti dalam kutipan teks berikut.

\section{Untuk salat tarawih saja mereka harus ke India, menempuh jarak yang cukup jauh. Mereka butuh tumpangan mobil untuk ke sana. tapi mereka tidak patah semangat tetap melaksanakan salat, "kata Illiza...}

Melalui teks berita tersebut terlihat usaha media dalam memperlihatkan bagaimana warga Indonesia sebagai saudara sesama umat muslim saling membantu diantara sesamanya. Begitupun yang dilakukan oleh Wali Kota Aceh dalam teks dengan judul Wali Kota Banda 
Aceh: Kuasai Alquran, Rohingya Kuasai Dunia memperlihatkan mengenai rasa solidaritas yang dibangun didasarkan pada rasa sesama umat muslim. Cara yang digunakan pun dengan hadirnya ia di acara buka puasa serta sahur bersama yang diadakan di pengungsian Rohingya. Di sisi lain, gerakan yang dilakukan oleh masyarakat Indonesia dalam menggalang dana untuk para pengungsi Rohingya juga tidak luput dalam pemberitaan mengenai upaya yang telah dilakukan warga Indonesia dalam membantu Etnis Muslim Rohingya.

Di sisi lain, pengedepanan mengenai peran pemerintah Indonesia dalam membantu muslim Rohingya juga menjadi pemberitaan. Dalam teks-teks berita yang disajikan laman viva.co.id, peran pemerintah seperti bantuan yang diberikan pemerintah daerah serta pemerintah pusat dalam membantu menyediakan tempat tinggal, makanan, serta sarana prasarana seperti sekolah bagi anak-anak pengungsi inipun tidak luput dalam pemberitaan. Seperti teks berita dengan judul Pemda Aceh Bangun Kompleks Pengungsi Rohingya (4 Juni2015). Melalui teks berita digambarkan mengenai bagaimana upaya pemerintah daerah dalam menyediakan sarana tempat tinggal bagi 332 pengungsi Etnis Rohingya asal Myanmar. Seperti dalam kutipan berita berikut.

Pemda Aceh Utara telah menyediakan lokasi dan tempat yang layak dan memenuhi standar untuk pengungsi serta menyediakan fasilitas yang dibutuhkan oleh pengungsi "kata Humas, Kabupaten Aceh Utara Amir Hamzah kepada viva. co.id...Tempat penampungan yang baru ini, Amir mengatakan, dibangun setengah permanen di lahan seluat tiga hektar milik pemerintah Aceh Utara. Tempat tersebut dibangun layaknya komplek yang sudah dilengkapi berbagai sarana, seperti kamar mandi dan air bersih yang memadai, sarana belajar bagi anak-anak, serta tempat ibadah seperti musala.
Melalui pemberitaan tersebut terlihat upaya yang telah dilakukan Pemda Aceh Utara. Bahkan dalam penyediaan layanan, Pemda memberikannya tidak alakadarnya saja. Tempat pengungsian lama yang dianggap kurang layak akan ditinggalkan oleh para pengungsi. Pemerintah bahkan membangun tempat pengungsian baru yang lebih memadai bagi para pengungsi. Melalui upaya pembangunan wacana tersebut jelas terlihat upaya pemerintah dalam membantu para pengungsi Rohingya. Melalui teks, pembaca berita akan dapat memperoleh mengenai gambaran kondisi pengungsian yang ditinggali oleh pengungsi Rohingya selama ini masih jauh dari memadai. Melalui konstruksi inipun masyarakat pembaca akan memperoleh dampak psikologis yang berdampak pada rasa solidaritas dan empati yang dibentuk melalui wacana ini. Selain teks ini, juga terdapat teks berita berjudul Ratusan Pengungsi Rohingya Telah Dipindahkan ke Tempat Baru (14/05/ 2015). Melalui pemberitaan inipun terlihat bagaimana konstruksi media viva.co.id dalam membentuk wacana usaha yang telah dilakukan pemerintah dalam membantu para pengungsi Etnis Muslim Rohingya.

\section{Dampak Pembentukan Wacana Solidaritas Muslim Indonesia terhadap Muslim Rohingya Bagi Kelompok Lain}

Didasarkan pada pembahasan pada dua sub-bab sebelumnya, maka terlihat bagaimana konstruksi wacana mengenai pengungsi Etnis Rohingya yang ada di Indonesia dibentuk oleh media viva.co.id. representasi yang ditampilkan dalam ketujuh teks pemberitaan lebih pada pembentukan wacana solidaritas kemanusiaan terhadap Etnis Rohingya yang mencari suaka ke beberapa negara, salah 
satunya Indonesia yang digambarkan tidak memperoleh keadilan di negaranya serta pengedepanan upaya pemerintah dan rakyat Indonesia dalam membantu para pengungsi tersebut. Akan tetapi, bentuk wacana yang ditampilkan dalam ketujuh wacana yang terdapat pada teks berita viva.co.id seolaholah telah memarjinalkan posisi kelompok lainnya yang dianggap tidak sesuai dengan realitas yang seharusnya terjadi. Seperti dalam teks berita berjudul Hizbut Tahrir Kritik Sikap Diam Suu Kyu Soal Rohingya (29/05/2015).

Menurut Juru Bicara HTI, Ismail Yusanto, Suu Kyi seolah abai dengan tragedi kemanusian di negerinya itu. Padahal Suu Kyi adalah aktivis pembela hak asasi manusia dan peraih nobel perdamaian. Namun sejauh ini tak ada komentar apa pun darinya.

Dalam kutipan di atas terlihat dalam memberitakan mengenai sikap dari Suu Kyi sebagai peraih nobel perdamaian yang berdiam diri saja terlihat adanya bentuk inclusion. Proses inklusi yang digunakan dalam wacana tersebut berbentuk strategi diferensiasiindiferensiasi. Melalui kalimat kedua dalam kutipan teks berita di atas secara tidak langsung membedakan mengenai sikap antara Suu Kyi yang diam saja dalam menghadapi permasalahan, di sisi lain dengan menampilkan bahwa ia merupakan seorang peraih nobel perdamaian. Teks tersebut dikatakan memarjinalkan karena teks tersebut memisahkan dua hal sedemikian rupa tanpa penjelasan mengenai kondisi realitas yang disajikan sebagai pembanding. Dalam teks tersebut digambarkan seolah sebagai seorang peraih nobel perdamain Suu Kyi tidak melakukan apapun dalam permasalahan ini. Berkaitan dengan hal tersebut, dengan tidak adanya penelusuran serta adanya argumentasi dari Suu
Kyi yang menerangkan realitas sebenarnya dari kondisi tersebut jelas memperlihatkan adanya ketidakseimbangan pada kedua proposisi dalam kalimat-kalimat tersebut. Akibatnya, yang tergambar di dalam teks ialah perbedaan padnangan antara cara yang dianggap seharusnya dengan cara pandang yang dipandang tidak patut dilakukan.

Di sisi lain dalam teks berita juga digunakan strategi inklusi berupa determinasiindeterminasi. Seperti dalam teks berita berjudul Cabai, Sirih, dan Kisah Tarawih Etnis Rohingya (20/05/2015) berikut.

Untuk salat tarawih saja mereka harus ke India, menempuh jarak yang cukup jauh. Mereka butuh tumpangan mobil untuk ke sana. Tapi mereka tidak patah semangat tetap melaksanakan salat, "kata Illiza...

Dalam teks tersebut aktor sosial yang dibicarakan tidak dijelaskan secara spesifik, tetapi dengan menggunakan kata ganti "mereka". Efek dari digunakannya jenis strategi ini berdampak pada bagaimana aktor sosial dalam berita digambarkan, yaitu lebih kepada upaya penggunaan aktor jamak sebagai pendukung tindakan dalam peristiwa untuk menarik hati dari pembacanya (mendukung konstruksi ideologi yang coba diberikan kepada pembacanya). Padahal penggunaan kata "mereka" merujuk pada keseuruhan subjek yang dibicarakan, akan tetapi upaya perluasan subjek dalam teks berita tersebut mengesankan kepada pembaca bahwa semua masyarakat Etnis Rohingya ketika akan salat Tarawih haruslah terlebih dahulu bersusah payah pergi ke India dengan menumpang mobil. Didasarkan pada fakta bahwa tidak semua realitas tersebut terjadi di Myanmar. Akan tetapi perbandingan mengenai hal tersebut tidak disajikan dalam teks pemberitaan. 
Didasarkan pada ketujuh teks yang digunakan dalam pengonstruksian mengenai wacana solidaritas yang dilakukan oleh warga dan pemerintah Indonesia akan selalu merujuk pada tindakan penindasan yang diterima Etnis Rohingya oleh warga dan Pemerintah Myanmar. Dalam strategi wacana tersebut kecenderungan yang digunakan dalam memarjinalkan kelompok lain (pemerintah Myanmar) dilakukan proses pengekslusian tidak dengan penggunaan kalimat. Akan tetapi kelompok tersebut benarbenar dikeluarkan dari teks dengan tidak adanya pembahasan dari sudut pandang kelompok ini. Padahal sebagai sebuah media, peran media seharunya menyajikan netralitas dalam suatu pemberitaan yang berasal dari dua sudut pandang nara sumber. Akan tetapi dalam ketujuh teks pengedepanan mengenai proses penindasan dan ketidakadilan yang diterima oleh para pengungsi Etnis Rohingya menjadi topik pembahasan berita yang selalu disajikan.

\section{SIMPULAN}

Jurnalistik dalam dunia pers Indonesia kini tidak lagi hanya berfungsi sebagai pengontrol jalannya pemerintahan. Peran media yang awalnya sebagai "medium" perantara yang menyampaikan informasi kepada khalayak dengan seimbang didasarkan pada fakta yang ada ternyata tidak terjadi. Melalui pemberitaan yang dilakukan oleh media viva.co.id di atas terlihat bagaimana wacana solidaritas Bangsa Indonesia sebagai negara dengan umat muslim terbesar di dunia hadir dan membantu sesama umat muslim dari negara lain yang sedang dilanda musibah. Terdapat banyak motif dalam penggambaran wacana kemanusiaan tersebut, mulai isu agama, kemanusiaan, rasa iba, dll. Akan tetapi dengan proses pengonstruksian terhadap suatu kelompok justru berdampak pada pemarjinalan terhadap kelompok lain. Porsi pemberitaan terhadap sudut pandang pemerintah Myanmar diabaikan, bahkan benar-benar dikeluarkan dalam pemberitaan. Pemerintah Myanmar justru lebih digambarkan dengan beragam citra negatif, begitu juga dengan para pengungsi Rohingya yang selalu digambarkan sebagai kelompok yang benar-benar sedang kesusahan dan benarbenar membutuhkan bantuan. Terdapat bobot pemberitaan yang tidak seimbang yang dilakukan oleh media viva.co.id yang berdampak pada pemarjinalan kelompok lain. 


\section{DAFTAR PUSTAKA}

Ardianto, Elvinaro. 2012. Analisis Wacana Kritis Pemberitaan Harian Pikiran Rakyat dan Harian Kompas Sebagai Public Relations Politik dalam Membentuk Branding Reputation Presiden Susilo Bambang Yudhoyono (SBY). Jurnal Ilmu Komunikasi, Vol 2. No. 1.

Badara, Aris. 2012. Analisis Wacana: Teori, Metode, dan Penerapannya pada Wacana Media. Jakarta: Kencana Prenanda Media Grup

Cahaya, A I. Rohingya, Kroban Minoritas yang Terusir Dari Negaranya. (www.setkab.go.id/artikel-5309-html). Diakses 29 Mei 2015

Denzin, N K dan Lincoln Y S (ed). 1994. Handbook of Qualitative Research. London: Sage Publication.

Eriyanto. 2012. Analisis Wacana: Pengantar Analisis Teks Media. Yogyakarta: LKIS.

Fitriyani, Amalia. 2011. Analisis Wacana Kritis Pencitraan Susilo Bambang Yudhoyono Sebagai Politikus dalam Buku Pak Beye dan Politiknya Terbitan
PT. Kompas Media Nusantara. Skripsi tidak terbitkan. Yogyakarta: Fakultas Ilmu Sosial dan Politik Universitas Pembangunan Nasional "Veteran"

Ibrahim, I.S, dan Suranto, H. 1998. Wanita dan Media: Konstruksi Ideologi Gender dalam Ruang Publik Orde Baru. Bandung: Remaja Rosda Karya

Leeuwen, Theo Van. 2008. Discourse and Practice: New Tools for Critical Discourse Analysis. New York: Oxford University Press.

Romli, Asep Syamsul M. Jurnalistik Online: Pengantar Praktis Mengelola Media Online. Bandung: Nuansa

Suganda, Dadang,. Wagiati,. Darmayanti, Nani,.. 2007. Representasi Sosok Tenaga Kerja Wanita (TKW) Indonesia dalam Wacana Berita Pada Harian Umum Utusan Malaysia dan Harian Umum Kompas Indonesia: Kajian Analisis Wacana Kritis. Makalah Simposium Kebudayaan IndonesiaMalaysia ke X. Bandung: Fakultas Sastra Universitas Padjajaran. 